\title{
POLA ALOKASI WAKTU DAN KONTRIBUSI PENDAPATAN PEREMPUAN PEDAGANG SAYURAN DI PASAR PINASUNGKULAN KAROMBASAN MANADO
}

\author{
Angelina Pesik \\ Jenny Baroleh \\ Rine Kaunang
}

\begin{abstract}
This study aims to determine the pattern of time allocation of women vegetable traders and their contribution to the household income. This research was conducted in Pinasungkulan Market, Karombasan, Manado for two month from June to July 2016. The primary data was collected from interviews with 15 women vegetable sellers who have a family. Secondary data were obtained from Sub-office Pinasungkulan Market. Data analysis was used descriptive analysis techniques. The results showed that, in general, women vegetables traders in the Pinasungkulan Market have started selling vegetables after they were married. Because as wives, they realized that they have to support their husbands to earn money for a living because of their husband's income is not sufficient. Time allocation patterns of the woman vegetable seller shave used an average of 15 hours per day for all their activities. They are selling vegetables, domestic activities and others social activities. Their time allocation daily respectivley consists of sold vegetables activities spend on average 8.9 hours (59.40\%), for households 2, 6 hours/day (17.30\%) and for other activities such as watching television and attending worship and other social activities, an average of 3.5 hours (23.3\%). The conclusion from this study that the pattern of time allocation by women vegetable vendors in the Market of Pinasungkulan, Karombasan, women spend more time on economic activities than from domestic activities. Women vegetable sellers have earned average income of IDR 4.400 million per month with a $59.27 \%$ contribution to the family income. While their husband shave contributed to the family income is lower than the wife of 19.09\% with an average income of IDR 1.417 million per month. The contribution of other members of the household is income, especially children, are IDR 1.607 million per month (21.64\%). Therefore, it can be concluded that women vegetables traders in Pinasungkulan Market are primary source of support for family.
\end{abstract}

Keywords: women, vegetable traders, time allocation, contribution, income, Pinasungkulan Market, Manado City

ABSTRAK
Penelitian ini bertujuan untuk mengetahui pola alokasi waktu perempuan pedagang sayuran dan kontribusi pendapatan terhadap pendapatan keluarga. Penelitian dilaksanakan di Pasar Pinasungkulan Karombasan Manado selama dua bulan dengan menggunakan data primer berasal dari wawancara dengan 15 perempuan yang telah berkeluarga yang berjualan sayuran hijau. Data sekunder diperoleh dari Kantor Sub Dinas Pasar Pinasungkulan dan dianalisis dengan menggunakan teknik analisis deskriptif. Hasil penelitian menunjukkan bahwa perempuan pedagang sayuran di pasar Pinasungkulan Karombasan umumnya berstatus ibu rumahtangga dan umumnya usaha berjualan sayuran ini dimulai setelah perempuan menikah. Istri merasa perlu membantu suami mencari nafkah karena penghasilan dari suami tidak mencukupi. Pola alokasi waktu menunjukkan bahwa perempuan pedagang sayuran melakukan kegiatan rata-rata sebanyak 15 jam per hari. Kegiatan mencari nafkah (berjualan sayuran) rata-rata menghabiskan waktu sebanyak 8,9 jam dan untuk rumah tangga sebanyak 2,6 jam/hari. Untuk kegiatan lain seperti menonton televisi dan menghadiri ibadah dan kegiatan sosial lainnya, rata-rata sebanyak 3,5 jam. Pendapatan tertinggi diperoleh istri dengan rata-rata pendapatan Rp 4.400.050 per bulan dengan kontribusi sebesar 59,27 \%. Kontribusi suami dalam pendapatan keluarga lebih rendah dari istri yakni sebesar 19,09 \% dengan rata-rata pendapatan Rp 1.417.000/bulan. . Sumbangan anggota rumah tangga dari anak yang bekerja dan tinggal serumah Rp 1.607.000 per bulan $(21,64 \%)$. Kesimpulan dari penelitian ini bahwa pola alokasi waktu oleh perempuan yang berdagang sayuran di Pasar Pinasungkulan Karombasan Manado lebih banyak mencurahkan waktunya $(59,40 \%)$ untuk berjualan sayuran (economic production) dibandingkan dengan mengurus rumahtangga (domestic production) (17,30\%), sehingga usaha ini merupakan aktivitas perempuan sebagai pencari nafkah utama dalam keluarga. Kontribusi pendapatan ibu rumah tangga yang berusaha di bidang penjualan sayuran di pasar sekitar 59,27 persen terhadap pendapatan rumah tangga.

Kata kunci : perempuan, pedagang sayuran, alokasi waktu, kontribusi, pendapatan keluarga, Pasar Pinasungkulan, Kota Manado 


\section{PENDAHULUAN}

\section{Latar Belakang Masalah}

Pembangunan menghasilkan perubahan struktur pekerjaan perempuan di perkotaan yang mencerminkan suatu proses pengalihan di sektor non pertanian. Hal ini terlihat dari kosentrasi perempuan di bidang pertanian pada awal Pembangunan Jangka Panjang Tahap Pertama, sedangkan pada akhir-akhir ini jumlah perempuan semakin meningkat di sektor non pertanian, seperti perdagangan, jasa, industri, dan pembantu rumah tangga di kota-kota. Namun demikian, masih ada sebagian perempuan yang hanya melakukan pekerjaan rumah tangga.

Diketahui bahwa pembangunan membawa dampak bagi kemajuan di berbagai dimensi kehidupan masyarakat, seperti pendidikan lebih tinggi, kesehatan masyarakat dan harapan hidup lebih baik, serta penggunaan teknologi produksi lebih maju, yang pada akhirnya meningkatkan pendapatan masyarakat. Pembangunan juga membawa perubahan tatanan kehidupan masyarakat, baik di pedesaan maupun perkotaan, yang pada gilirannya mempengaruhi kehidupan dan hubungan yang baru antara lakilaki dan perempuan.

Persepsi lama bahwa perempuan hanya berperan di dalam rumahtangga menjadi mitos belaka oleh karena sekarang ini perempuan juga telah memasuki aktivitas di luar rumahtangga yang merupakan perwujudan peran ganda. Namun demikian, tujuan utama perempuan terlibat dalam pasar kerja atau bekerja sampingan di sektor non pertanian tidak lain untuk mencari nafkah untuk kelangsungan ekonomi rumah tangga Berdasarkan kenyataan ini maka perempuan perlu mengatur waktu sebaik-baiknya agar tercipta keseimbangan antara peran di dalam rumahtangga dan di luar rumahtangga.

Keseimbangan antara peran di dalam rumahtangga dan di luar rumahtangga bagi perempuan nantinya akan berpengaruh terhadap ekonomi keluarga secara khusus. Keluarga merupakan unit terkecil dalam masyarakat yang terdiri dari ayah sebagai kepala keluarga yang kedudukannya mencari nafkah, ibu yang memiliki peran di dalam keluarga yang bisa diartikan menjalankan fungsi sebagai memasak, melahirkan dan mengurus rumahtangga. Namun demikian, di dalam meningkatkan ekonomi keluarga khususnya keluarga-keluarga yang tingkat ekonominya relatif rendah, perempuan yang bekerja di luar rumah, maka keseimbangan antara peran dalam rumahtangga dan di luar rumahtangga menjadi bahan pertimbangan dalam hal curahan waktu kerja (tingkat intensitasnya) dalam hal ini manajemen waktu yang dicurahkan demi keluarga.

Pedagang sayur di pasar banyak melibatkan perempuan, baik sebagai ibu rumah tangga maupun sebagai pekerja di luar rumah. Keadaan ini antara lain disebabkan bahwa usaha ini berlangsung relatif mudah dan sederhana, tidak membutuhkan keterampilan khusus, serta modal yang digunakan relatif kecil. Oleh karena itu perempuan pedagang sayur melakukan peran sebagai pencari nafkah dan sebagai pengurus rumah tangga. Perempuan pedagang sayur mempunyai potensi dalam peningkatan pendapatan keluarga yang nantinya akan meningkatkan kesejahteraan dalam rumahtangga.

Walaupun usaha ini penting untuk mewujudkan peran ganda perempuan, pada umumnya pengetahuan mengenai perempuan sebagai pedagang sayur di pasar dan pola alokasi waktu (manajemen waktu) serta keadaan rumah tangganya belum diketahui. Oleh karena itu, diperlukan penelitian guna memperoleh gambaran yang lebih jelas, baik mengenai pola alokasi waktu perempuan yang bekerja, dan sumbangannya terhadap pendapatan rumah tangga.

\section{Perumusan Masalah}

Berdasarkan latar belakang yang telah dikemukakan maka yang menjadi permasalahan dalam penelitian ini yaitu:

1. Bagaimana pola alokasi waktu perempuan pedagang sayuran di Pasar Pinasungkulan Karombasan Manado?

2. Bagaimana kontribusi pendapatan dari perempuan pedagang sayuran terhadap pendapatan rumah tangga?

\section{Tujuan Penelitian}

Penelitian ini bertujuan untuk mengetahui:

1. Pola alokasi waktu perempuan pedagang sayuran di Pasar Pinasungkulan Karombasan Manado.

2. Kontribusi pendapatan dari perempuan pedagang sayuran terhadap pendapatan rumah tangga. 


\section{Manfaat Penelitian}

Penelitian ini dapat digunakan sebagai pengetahuan terhadap pola alokasi waktu dan kontribusi perempuan terhadap pendapatan rumahtangga dalam keluarga. Sebagai tambahan penghasilan dalam rumah tangga keluarga serta sebagai informasi dan bahan pertimbangan kebijakan oleh pemerintah dan sebagai upaya meningkatkan peran perempuan dalam pembangunan.

\section{METODOLOGI PENELITIAN}

\section{Metode Pengumpulan Data}

Penelitian ini menggunakan data primer dan data sekunder. Data primer diperoleh melalui wawancara langsung dengan responden berdasarkan daftar pertanyaan yang telah disiapkan, sedangkan data sekunder diperoleh dari instansi yang terkait langsung dengan penelitian dalam hal ini Kantor Dinas Pasar Kota Manado Sub Dinas Pasar Pinasungkulan Karombasan serta telaah pustaka yang berkaitan dengan penelitian.

\section{Metode Pengambilan Sampel}

Populasi dalam penelitian ini adalah seluruh perempuan pedagang sayuran di Pasar Pinasungkulan Karombasan Manado yang berjumlah 153 orang. Pengambilan sampel dilakukan secara sengaja (Purposive Sampling) dengan dibatasi pada perempuan yang berjualan sayuran hijau yang sudah berkeluarga dan masih mempunyai suami. Jumlah sampel sebagai responden yaitu sebanyak 15 perempuan penjual sayuran hijau yang sudah berkeluarga dan masih mempunyai suami. Pencatatan alokasi waktu dilakukan selama satu hari penuh pada kegiatan/aktivitas wanita. Di samping itu informasi lain juga diperoleh dari beberapa informan yang ada relevansinya dengan tujuan penelitian.

\section{Konsep Pengukuran Variabel}

Variabel-variabel yang diukur dalam penelitian ini, adalah:

1. Karakteristik responden dalam hal ini perempuan pedagang sayuran berupa umur, tingkat pendidikan, jumlah tanggungan keluarga, lamanya berjualan sayuran, pekerjaan suami.

2. Pola alokasi waktu oleh perempuan yang beraktivitas sebagai penjual sayuran dan pada aktivitas rumah tangga.(waktu yang diperlukan dalam aktivitas berjualan dan melakukan aktivitas rumah tangga dalam keluarga dihitung dalam jumlah jam/hari (1 x 24 jam)

3. Kontribusi pendapatan ibu rumah tangga yang beraktivitas di bidang penjualan sayuran terhadap pendapatan rumah tangga $(\%)$.

4. Pendapatan dalam keluarga di hitung berdasarkan:

a. Pendapatan istri yaitu: pendapatan ibu rumah tangga yang didapat dari hasil penjualan sayuran dikurang biaya pengeluaran dalam berjualan (retribusi, kebersihan, angkutan dan tenaga kerja)(Rp/bulan)

b. Pendapatan suami yaitu pendapatan yang diperoleh dari berbagai pekerjaan yang dijalankan, yang dihitung berdasarkan (Rp/bulan)

c. Pendapatan anak yaitu dari anak lakilaki dan perempuan yang belum menikah tetapi sudah bekerja (Rp/bulan)

\section{Metode Analisis Data}

Hasil penelitian dianalisis secara deskriptif (descriptive analysis) (Sugiyono, 2003) dimana penelitian dilakukan untuk mengkaji karakteristik perempuan pedagang sayuran, pola alokasi waktu, usaha serta kontribusi terhadap pendapatan rumah tangga.

Kemudian dibuat kesimpulan untuk menjawab permasalahan penelitian dengan langkah-langkah sebagai berikut: a). Mereduksi data, kalau banyak disederhanakan dan disesuaikan. b). Display data, mengklasifikasikan masing-masing data supaya lebih jelas dan c). Pengambilan kesimpulan.

Semua data yang dianalisis disajikan dalam bentuk tabel dan untuk melihat besarnya kontribusi perempuan sebagai ibu rumah tangga terhadap pendapatan keluarga digunakan rumus: 


\begin{tabular}{|l|l|}
\hline $\begin{array}{l}\text { Kontribusi pedagang sayur } \\
\text { Terhadap Total Pendapatan } \\
\text { Keluarga }\end{array}$ & $=\frac{\text { Pendapatan perempuan pedagang sayuran }}{*}$ \\
Total Pendapatan Keluarga
\end{tabular}$* 100 \%$

*) Pendapatan perempuan pedagang sayuran adalah total penerimaan perempuan pedagang sayuran dikurangi total biaya yang dikeluarkan oleh perempuan pedagang sayuran.

${ }^{* * *)}$ Total Pendapatan Keluarga adalah Pendapatan Suami + Pendapatan Istri (perempuan pedagang sayuran) + Pendapatan anak yang sudah bekerja.

\section{HASIL DAN PEMBAHASAN}

\section{Gambaran Umum Pasar Pinasungkulan Karombasan Manado}

Pasar Pinasungkulan lebih dikenal oleh masyarakat dengan Pasar Karombasan merupakan salah satu pasar tradisional kedua terbesar setelah Pasar Bersehati yang ada di Kota Manado terletak di Kelurahan Karombasan Utara Lingkungan III Kecamatan Wanea. Pengertian pasar tradisional adalah tempat bertemunya pembeli dan penjual, berfungsi menyediakan barang atau jasa untuk di jual sehingga terjadi pemindahan milik. Dengan kata lain bahwa pasar adalah jumlah seluruh permintaan barang atau jasa oleh pembeli-pembeli potensial.

Pasar tradisional sebagai kerumunan pedagang dan pembeli yang memperjualkan barang/jasa. Pelaku di pasar adalah pedagang kecil, yang sebagian besar menjual komoditas pertanian (sayuran, buah-buahan, beras dan lain-lain), kerajinan rakyat (tikar, topi), dan lain-lain (ayam, telur, daging). Pasar merupakan tempat yang umumnya menjadi incaran masyarakat untuk mencari barang yang mereka butuhkan sehari-hari dan mereka sering mencarinya di pasar tradisional. Pada umumnya yang dijual di pasar tradisional lebih murah dan dapat terjadi tawar menawar dibandingkan dengan pasar moderen. Pasar tradisional biasanya dikunjungi oleh masyarakat kelas menengah ke bawah, walaupun tidak menutup kemungkinan masyarakat ekonomi atas juga memanfaatkan keberadaan pasar tradisional ini.
Luas pasar Pinasungkulan Karombasan menurut data Dinas Pasar kota Manado yaitu \pm 2 ha dengan jumlah pedagang yang berjualan sebanyak 1300-an pedagang, termasuk didalamnya perempuan pedagang sayuran sebanyak 150 orang. Jumlah kios permanen sebanyak 170 buah, bak-bak penjualan (lapak) bantuan Inpres berjumlah 63 buah,dan tendatenda pelataran sebanyak 700 buah.

Aktivitas pasar ini berlangsung setiap hari dimulai dari jam 04.00 subuh sampai jam 21.00 (jam 9 malam). Aktivitas paling ramai berlangsung dari jam 07.00 sampai jam 11.00 dimana pada jam-jam tersebut sangat ramai dengan orang yang berbelanja. Pada jam 12.00 sampai jam 15.00 agak sepi dan nanti sekitar jam 16.00 mulai ramai lagi dan berhenti pada jam 21.00 .

Kedudukan pasar ini berhadapan dengan pertokoan Pinasungkulan Plaza dengan terminal Karombasan yang dilalui oleh semua kendaraan jenis angkutan dari luar kota. Untuk akses masuk ke pasar dapat dilalui dengan jenis angkutan dari beberapa wilayah melalui jalan lingkar pasar yang sudah diaspal. Batas-batas dari pasar Pinasungkulan yaitu: sebelah utara berbatasan dengan Kelurahan Pakowa, sebelah selatan dengan Kelurahan Karombasan, sebelah barat dengan Kelurahan Ranotana Weru.

Pasar Pinasungkulan Karombasan Manado merupakan tempat pertemuan pedagang dari berbagai daerah yang didominasi dari Minahasa dan ada juga yang berasal dari Kotamobagu dan Gorontalo. Khusus wanita pedagang sayuran terdiri dari berbagai latar belakang suku yang berbeda seperti Minahasa, Sangir dan Gorontalo. Mereka menempati jualan mereka di tenda-tenda beratap seng atau terpal plastik untuk menghindari hujan dan panas dengan jualan di atas meja, atau hanya beralaskan tikar atau plastik.

Adapun jenis sayuran yang diperdagangkan oleh wanita di pasar ini yaitu: caisin, kangkung, bayam, gedi, daun ubi, daun bawang, rempah campur (baramakusu, daun lemong, balakama), petsai, pok coy, seldrei, daun leilem, daun papaya, daun ganemo 
(sayuran berwarna hijau), patura, kol, bunga kol, labu (sambiki), kentang, wortel, rebung, kacang panjang, buncis, paria, terong, bunga papaya, ketimun dan ketimun jepang.

\section{Deskripsi Responden}

Responden yang menjadi sampel dalam penelitian ini ialah para perempuan pedagang sayuran yang sudah berkeluarga dan mempunyai suami dan berjualan di pasar tidak tinggal di lapak dan pulang ke rumah setiap hari untuk mengurus rumahtangga. Berikut ini dijelaskan karakteristik responden menurut umur, lama berdagang sayuran, tingkat pendidikan, dan jumlah tanggungan keluarga, serta penghasilan, pekerjaan anggota keluarga lainnya, serta alasan perempuan berdagang sayuran.

\section{Umur Responden}

Faktor umur mempunyai hubungan yang sangat erat dengan pengalaman hidup seseorang. Umur juga mempunyai hubungan dengan lamanya berdagang sayuran, pengalamannya menjalani kehidupan sebagai individu dalam interaksinya dengan individu lain dalam lingkungan sosial, bahkan lingkungan fisik alamiah.

\begin{tabular}{ccc} 
Tabel & \multicolumn{3}{c}{ 1. Distribusi } & Responden & menurut \\
Kelompok Umur & \\
\hline Kelompok Umur & Jumlah & Persen \\
\hline$<50$ & 4 & 26,67 \\
$50-59$ & 9 & 60,00 \\
$>59$ & 2 & 13,33 \\
\hline Jumlah & 15 & 100,00 \\
\hline
\end{tabular}

Sumber: Data Primer, Juli 2016

Tabel 1 memberikan gambaran bahwa umur responden perempuan pedagang sayuran di Pasar Pinasungkulan Karombasan Manado, berkisar antara 39 tahun sampai dengan 62 tahun dengan rata-rata umur 53,13 tahun. Namun demikian pada kategori umur lebih besar dari 59 tahun terdapat 2 responden perempuan pedagang sayuran yaitu umur 60 tahun dan 62 tahun yang secara fisik kemampuannya mulai menurun. Berdasarkan umur responden maka perempuan pedagang sayuran dalam penelitian ini didominasi oleh perempuan berumur 50 tahun sampai 59 tahun.

\section{Lama Berjualan di Pasar}

Lama menjadi pedagang sayuran di pasar sepertinya halnya umur, mempunyai hubungan erat dengan pengalamannya dalam berjualan di pasar. Tabel 2 menunjukkan lamanya responden menjadi pedagang sayuran yaitu rata-rata 21,17 tahun, yang paling rendah yakni 6 tahun dan paling lama berjualan sayuran yaitu 35 tahun.

Tabel 2. Distribusi Responden menurut Lama Menjadi Pedagang Sayuran di Pasar Pinasungkulan Karombasan Manado

\begin{tabular}{ccc}
\hline $\begin{array}{c}\text { Lama } \\
\text { (tahun) }\end{array}$ & Jumlah (orang) & Persen \\
\hline$<16$ & 6 & 40,00 \\
.$>16$ & 9 & 60,00 \\
\hline Jumlah & 15 & 100,00 \\
\hline
\end{tabular}

Sumber: Data Primer, Juli 2016

Bila dihubungkan dengan lamanya menjadi pedagang sayuran, pengalaman hidup menjadi penjual sayuran, rata-rata sudah memiliki pengalaman hidup yang membentuk mereka tetap eksis dengan pekerjaan mereka walaupun ditambah dengan mengurus rumah tangga dan kehidupan bersosial.

\section{Tingkat Pendidikan}

Tingkat pendidikan berkaitan erat dengan bidang pekerjaan dan usaha yang dilakukan seseorang. Berdasarkan temuan di lokasi penelitian dari 15 responden yang diteliti, hanya 2 orang yang berpendidikan SMA dan SMK sedangkan yang 13 wanita pedagang sayuran sebanyak 6 orang berpendidikan Sekolah Dasar dan 7 orang berpendidikan Sekolah Lanjutan Tingkat Pertama (SMP).

Gambaran tingkat pendidikan tersebut bila dihubungkan dengan pekerjaan responden, maka mereka yang berpendidikan SMA (ada 2 responden) umumnya sudah tidak ada pekerjaan lain di luar sebagai pedagang sayuran. Mereka tidak ada keterampilan dan pengalaman lain untuk masuk dalam bidang pekerjaan yang lain selain berjualan sayuran di pasar.

\section{Tanggungan dalam Keluarga}

Jumlah atau banyaknya tanggungan keluarga mempunyai hubungan erat dengan umur responden sebagai pedagang sayuran di pasar. Jumlah tanggungan 1-2 orang pada 
umumnya responden pasangan muda sekitar berumur dibawah 40 tahun dan atau sudah berumur di atas 50 tahun. Responden yang berumur lebih dari 50 tahun terkadang anakanak mereka sudah menikah sehingga tidak menjadi tanggungan lagi. Mereka yang tergolong dalam kategori 50 tahun ke atas ada tanggungan keluarga jika mereka mempunyai orangtua yaitu kakek dan nenek yang tinggal dalam keluarga mereka.

Jumlah tanggungan keluarga dari 15 responden, sebanyak 66,67 persen (10 responden) yang hanya mempunyai satu orang tanggungan. Sementara itu, ada 20 persen yaitu 3 responden yang mempunyai tanggungan 2 sampai 3 orang, Ada dua responden yang mempunyai tanggungan lebih dari 3 orang. Anak-anak mereka ada yang sedang mengikuti pendidikan di jenjang SLTP dan SLTA.

\section{Penghasilan Perempuan Pedagang Sayuran}

Pada Tabel 3 memberikan gambaran mengenai penghasilan perempuan pedagang sayuran yang sudah dikonversi ke rupiah per bulan. Penghasilan responden dimaksud ialah pendapatan dari hasil rata-rata per hari yang diterima dalam bentuk penjualan sayuran. Penghasilan ini ada responden yang mendapatkan Rp 100.000 sampai Rp 300.000 per hari dan ada yang Rp 75.000/hari.

\section{Tabel 3. Rata-rata Penghasilan Perempuan Pedagang Sayuran (Rp/Bulan) di Pasar Pinasungkulan Karombasan Manado}

\begin{tabular}{ccc}
\hline $\begin{array}{c}\text { Penghasilan } \\
\text { (Rp/bulan) }\end{array}$ & $\begin{array}{c}\text { Jumlah } \\
\text { Responden }\end{array}$ & Persen \\
\hline$<=6.000 .000$ & 9 & 60.00 \\
$>6.000 .000$ & 6 & 40.00 \\
\hline Jumlah & 15 & 100,00 \\
\hline
\end{tabular}

Sumber: Data Primer, Juli 2016

Berdasarkan penghasilan 15 responden perempuan pedagang sayuran diperoleh penghasilan rata-rata $\mathrm{Rp} \quad 6.250 .000 /$ bulan dengan penghasilan yang paling rendah yaitu Rp 2.250.000/bulan dan penghasilan yang paling tinggi yaitu Rp 9.000.000/bulan. Dalam Tabel 3 tersebut diperoleh kategori penghasilan yang rendah sebanyak 9 responden dan responden yang dikategorikan berpenghasilan tinggi sebanyak 6 orang.

Penghasilan responden ini jumlahnya tidak menentu setiap hari tergantung responden mendapatkan sayuran lebih cepat dari mobilmobil angkutan yang memasok bahan sayuran dari kebun. Jika mereka terlambat untuk datang mengambil bahan sayuran untuk dijual maka harganya akan lebih mahal karena sudah berada di tangan kedua dari pemasok sayuran ini.

\section{Alasan Perempuan Berjualan Sayuran di Pasar}

Beberapa faktor pendorong yang menyebabkan perempuan berdagang sayuran di pasar yaitu: 1). tidak ada pekerjaan lain, 2). pendapatan suami tidak mencukupi, 3) mudah dikerjakan, 4). ingin memperoleh uang sendiri, 5) tidak ada keterampilan lain, 6) tidak memerlukan modal yang besar dan sebagainya. Para responden mengatakan bahwa pendapatan suami saja dirasakan masih sangat kurang untuk memenuhi kebutuhan rumah tangga. Oleh sebab itu, mereka berusaha mencari tambahan nafkah guna mengatasi kekurangan tersebut. Hal ini menunjukkan bahwa istri juga bertanggungjawab dalam keuangan rumahtangganya walaupun dikatakan bahwa suami memikul tanggungjawab utama dalam mencukupi kebutuhan ekonomi rumah tangga. Alasan yang lain mereka mengatakan bahwa mereka ingin mencari uang sendiri, mengurangi ketergantungan pada suami, di samping kesadaran bahwa penghasilan suami saja tidak cukup. Tabel 4 menjelaskan tentang alasan responden perempuan pedagang sayuran memilih pekerjaan tersebut.

Para responden mempunyai alasan yang berbeda-beda dan mereka menganggap aktivitas ini sangat mudah dijalankan. Disamping itu, keterampilan dan kebiasaan sangat menentukan pula. Mereka memperoleh pengalaman dari orang tua, yang pada umumnya telah lebih dahulu berdagang sayuran di pasar. Usaha ini tetap mereka pertahankan maupun dilanjutkan dan usaha ini merupakan pilihan utama dalam mencukupi kebutuhan keluarga. 
Tabel 4. Alasan Memilih Pekerjaan Berjualan Sayuran di Pasar

1. Mudah dikerjakan Jumlah Responden (\%)

2. Tidak punya keterampilan lain

$15(100)$

3. Tidak ada pekerjaan lain

$15(100)$

4. Langsung menerima uang dan dapat diharapkan

$13(86,7)$

5. Menambah penghasilan keluarga

$9(60)$

6. Tidak perlu modal yang besar

$15(100)$

$13(86,7)$

7. Lain-lain (meneruskan usaha dari orangtua)

$5(33,3)$

Sumber: Hasil wawancara, Juli 2016

\section{HASIL PENELITIAN}

\section{Alokasi Waktu Anggota Rumah Tangga Responden}

Berikut ini hasil penelitian tentang alokasi waktu anggota rumahtangga dari perempuan pedagang sayuran di pasar Pinasungkulan Karombasan. Pembagian kerja dan alokasi waktu di antara perempuan pedagang sayuran, suami, dan anggota rumah tangga lain yang belum menikah dan masih tinggal serumah disajikan pada Tabel 5.

Berdasarkan hasil wawancara dengan responden perempuan pedagang sayuran di Pasar Pinasungkulan Karombasan, kegiatan rumah tangga diklasifikasikan menjadi 1). kegiatan yang berkaitan dengan produksi rumah tangga (home production) yang mencakup memasak, mencuci, membersihkan rumah dan mengasuh anak, 2). kegiatan mencari nafkah, dalam hal ini berjualan sayuran di pasar dan 3). aktivitas lain, seperti menonton televisi, mengikuti kegiatan kerohanian (ibadah kolom) dan Pembinaan Kesejahteraan Keluarga (PKK).

Berdasarkan manajemen waktu dari ibu rumah tangga yang berdagang sayuran di pasar Pinasungkulan Karombasan Manado yang ditunjukkan dalam Tabel 6 diketahui bahwa kegiatan-kegiatan yang dilakukan oleh ibu-ibu setiap hari dimulai pada subuh dan pagi hari sampai menjelang malam hari lebih di dominasi mengurus sayuran yang akan dijual dan menjualnya di pasar.

Tabel 5. Rata-rata Waktu yang dicurahkan Anggota Rumah Tangga Responden pada Beberapa Kegiatan (jam/hari)

\begin{tabular}{|c|c|c|c|c|}
\hline \multirow[b]{2}{*}{$\begin{array}{c}\text { Status dalam Rumah } \\
\text { Tangga }\end{array}$} & \multicolumn{3}{|c|}{ Aktivitas yang dilakukan } & \multirow[b]{2}{*}{ Jumlah } \\
\hline & Rumah Tangga & Berjualan Sayuran & Lainnya & \\
\hline Responden & $\begin{array}{c}2,6(17,3 \%) \\
(42,6 \%)\end{array}$ & $\begin{array}{c}8,9(59,4 \%) \\
(94,7 \%)\end{array}$ & $\begin{array}{c}3,5(23,3 \%) \\
(20,0 \%)\end{array}$ & $\begin{array}{c}15,0(100 \%) \\
(45,4 \%)\end{array}$ \\
\hline Suami & $\begin{array}{c}1,0(11.1 \%) \\
(16,4 \%)\end{array}$ & $\begin{array}{c}0.5(5,6 \%) \\
(5,3 \%)\end{array}$ & $\begin{array}{c}7,5(83,3 \%)^{*} \\
(42,9 \%)\end{array}$ & $\begin{array}{c}9,0(100 \%) \\
(27,3 \%)\end{array}$ \\
\hline Anggota RT lainnya & $\begin{array}{c}2,5(27,8 \%) \\
(41,0 \%)\end{array}$ & $\begin{array}{c}(0 \%) \\
-\end{array}$ & $\begin{array}{c}6,5(72,2 \%) * \\
(37,1 \%)\end{array}$ & $\begin{array}{c}9,0(100 \%) \\
(27,3 \%)\end{array}$ \\
\hline Jumlah & $6,1(100 \%)$ & $9,4(100 \%)$ & $17,5(100 \%)$ & $33(100 \%)$ \\
\hline
\end{tabular}

Keterangan: * Termasuk mencari nafkah di luar usaha berjualan sayuran

Angka dalam tanda kurung pada baris pertama dari setiap item menunjukkan persentase terhadap alokasi waktu kerja total dan angka dalam tanda kurung pada baris kedua menunjukkan persentase terhadap jumlah alokasi waktu kerja setiap anggota rumah tangga. 
Tabel 6. Manajemen Waktu Perempuan yang Berjualan Sayuran di Pasar Pinasungkulan Karombasan Manado

\begin{tabular}{|c|c|c|}
\hline No & Jam & Kegiatan yang dilakukan Perempuan Pedagang Sayuran \\
\hline 1. & $02.00-03.00$ & $\begin{array}{ll}\text { - } & \text { Bangun pagi: doa pagi } \\
\text { - } & \text { Membereskan rumah } \\
\text { - } & \text { Menyiapkan sarapan dan menuju ke pasar }\end{array}$ \\
\hline 2 & $03.00-05.00$ & $\begin{array}{l}\text { - } \quad \text { Mengambil sayuran ke pemasok (suplier) di mobil } \\
\text { - } \quad \text { Memilah-milah dan mengikat sayuran } \\
\text { - } \quad \text { Membereskan dan mengatur tempat berjualan }\end{array}$ \\
\hline 3. & $05.00-13.00$ & $\begin{array}{l}\text { - Siap berjualan, melayani pembeli sambil sarapan pagi di tempat } \\
\text { berjualan } \\
\text { - } \quad \text { Siap pulang ke rumah }\end{array}$ \\
\hline 4. & $13.00-16.00$ & $\begin{array}{l}\text { - Memasak, makan siang, beres rumah, tidur siang dan menonton } \\
\text { televisi (Uttaran) }\end{array}$ \\
\hline 5. & $16.00-17.00$ & $\begin{array}{l}\text { - Hari tertentu ada rukun, ibadah kaum ibu, PKK; jika tidak tidur } \\
\text { siang atau nonton televise }\end{array}$ \\
\hline 6. & $19.00-20.30$ & $\begin{array}{l}\text { - Hari-hari tertentu ada ibadah kolom atau ibadah wilayah rohani } \\
\text { (Katolik) }\end{array}$ \\
\hline 7. & $21.00-02.00$ & - Tidur malam \\
\hline
\end{tabular}

Sumber: Data Primer, Juli 2016

Tabel 7. Kontribusi Terhadap Pendapatan Keluarga dalam Rp/Bulan

\begin{tabular}{cccc}
\hline $\begin{array}{c}\text { Anggota Rumah } \\
\text { Tangga }\end{array}$ & $\begin{array}{c}\text { Total Pendapatan } \\
\text { Rp/Bulan }\end{array}$ & $\begin{array}{c}\text { Rata-Rata Pendapatan } \\
\text { (Rp/bulan) }\end{array}$ & $\begin{array}{c}\text { Kontribusi } \\
(\%)\end{array}$ \\
\hline Istri & 66.000 .750 & 4.400 .050 & $59,27 \%$ \\
Suami & 21.255 .000 & 1.417 .000 & $19,09 \%$ \\
Anak yang bekerja & 24.105 .000 & 1.607 .000 & $21,64 \%$ \\
\hline Jumlah & 111.360 .750 & 7.424 .050 & $100 \%$
\end{tabular}

Sumber: Data Primer, Juli 2016; Jumlah responden $(\mathrm{n}=15)$

Tabel 6 menunjukkan bahwa keadaan ini berbeda kalau dibandingkan dengan ibu rumah tangga lain yang tidak berjualan sayuran di pasar tetapi berusaha di bidang lain, seperti berjualan di rumah, membuka warung yang aktivitasnya bisa dilakukan bersamaan dengan mengurus rumahtangga.

\section{Rata-rata Pendapatan Anggota Rumah Tangga Responden}

Kontribusi pendapatan dari masingmasing anggota rumah tangga dari perempuan pedagang sayuran ditunjukan dalam Tabel 7 .

Pendapatan keluarga pada Tabel 7 terdiri dari pendapatan rata-rata istri yang berjualan sayuran, rata-rata pendapatan suami dan rata-rata pendapatan anak yang masih tinggal serumah belum berkeluarga namun sudah bekerja dan memperoleh penghasilan. Pendapatan istri sebagai pedagang sayuran merupakan penerimaan bersih setiap hari setelah dikurangi dengan membayar retribusi, biaya tenaga kerja, biaya kebersihan dan biaya transportasi.

\section{Pembahasan}

Perempuan pedagang sayuran di pasar Pinasungkulan Karombasan umumnya berstatus ibu rumahtangga dan mempunyai suami dan ada pula anak yang belum menikah yang menjadi tanggungan karena tinggal serumah. Pada umumnya usaha berjualan sayuran ini dimulai setelah perempuan kawin. Istri merasa perlu membantu suami mencari nafkah karena penghasilan dari suami tidak mencukupi. 
Sebaliknya, suami memberi dukungan karena mereka merasakan tekanan ekonomi lebih besar bila hanya mengandalkan penghasilan rumah tangga dari suami sendiri.

\section{Pola Alokasi Waktu Perempuan Pedagang Sayuran di Pasar}

Perempuan dengan statusnya sebagai istri mempunyai peran yang berhubungan dengan kedudukannya sebagai ibu rumah tangga. Aktivitas-aktivitas dalam rumah tangga merupakan realisasi peran domestik yang dikenal pula sebagai produksi domestik. Perempuan berangsur-angsur tidak lagi terbelenggu dalam peran domestik saja. Hal ini disebabkan semakin beratnya tuntutan untuk memenuhi kebutuhan hidup rumah tangga dan semakin luas hubungan sosial perempuan di dalam masyarakat.

Secara umum, perempuan lebih banyak mencurahkan waktunya pada kegiatan rumah tangga (2,6 jam/hari) dibandingkan dengan suami mereka (1,0 jam/hari). Suami, sebaliknya lebih banyak mencurahkan waktunya untuk kegiatan lain $(7,5$ jam/hari), yaitu aktivitas mencari nafkah di luar usaha penjualan sayuran dan di luar kegiatan rumah tangga.

Tabel 5 juga menunjukkan bahwa perempuan pedagang sayuran melakukan kegiatan rata-rata sebanyak 15 jam per hari. Kegiatan mencari nafkah (berjualan sayuran) rata-rata menghabiskan waktu sebanyak 8,9 jam dan untuk rumah tangga sebanyak 2,6 jam/hari. Untuk kegiatan lain seperti menonton televisi dan menghadiri ibadah kolom, kaum ibu dan PKK rata-rata sebanyak 3 jam 30 menit. Waktu yang dicurahkan oleh suami rata-rata 6 jam lebih rendah daripada waktu yang dicurahkan oleh istri. Suami hanya mencurahkan waktunya untuk rumah tangga sebanyak 60 menit per hari. Peran ibu rumah tangga ketika sedang beraktivitas di luar rumah yakni berjualan sayuran dan mengikuti kegiatan sosial (ibadah dan PKK), digantikan oleh anggota keluarga lain, dalam hal ini anak, atau orang tua, atau kerabat yang tinggal dalam rumah yang masuk dalam tanggungan keluarga dan ini memberikan waktu rata-rata 2,5 jam/hari.

Dengan demikian istri yang bekerja pada sektor publik memiliki beban kerja yang sangat berat, karena disamping bekerja di luar rumah yaitu berjualan sayuran, masih harus menyelesaikan pekerjaan rumahtangga yang menyita waktu yang tidak sedikit. Meskipun suami turut membantu menyelesaikan urusan rumahtangga (domestik), namun waktu yang digunakan suami untuk urusan rumahtangga relatif lebih sedikit dibandingkan istri. Secara umum, perempuan lebih banyak mencurahkan waktunya pada kegiatan rumah tangga dibandingkan dengan suami mereka. Suami, sebaliknya lebih banyak mencurahkan waktunya untuk kegiatan lain, yaitu aktivitas mencari nafkah di luar berjualan sayuran dari istrinya dan di luar kegiatan rumah tangga.

Berdasarkan aktivitas yang dilakukan setiap anggota rumahtangga dari perempuan pedagang sayuran, untuk urusan rumahtangga maka istri lebih banyak mencurahkan waktunya yakni sebanyak 42,6 persen dibandingkan dengan suaminya hanya 16,4 persen. Jika istri berjualan sayuran di pasar maka pekerjaan rumahtangga digantikan oleh anak atau orangtua yang menjadi tanggungan dalam keluarga tersebut. Suami jarang membantu urusan rumahtangga kecuali hanya beberapa pekerjaan yang ringan saja seperti menyapu halaman dan sebagainya dan bukan untuk urusan memasak dan mencuci. Dalam keadaan istri yang bekerja menjual sayuran maka suami memberikan waktunya untuk membantu hanya sekitar 0,5 jam (30 menit) dan dilakukan pada pekerjaan berupa mengantar atau menolong membawa bahan sayuran ke pasar. Suami memberikan waktunya hanya relatif sedikit karena mereka mempunyai pekerjaan lain diluar aktivitas rumahtangga yaitu sebagai sopir, tukang ojek dan buruh harian lainnya. Ada sebanyak 3 suami yang tidak mempunyai pekerjaan namun mereka membantu berjualan sayuran dengan istri. Namun hal ini dilakukan pada saat istri pulang ke rumah siang hari dan digantikan suaminya untuk berjualan sampai sore hari.

Pada umumnya perempuan bekerja lebih lama jumlah jam kerjanya daripada suami mereka. Keadaan ini ditunjukkan dalam hasil penelitian ini bahwa dilihat dari jumlah jam kerja yang dicurahkan untuk kegiatan mencari nafkah (berjualan sayuran) dapat dikatakan bahwa perempuan bekerja berlebih (overworked). Rata-rata perempuan berdagang sayuran 8,9 jam dibandingkan dengan suami 
yang bekerja rata-rata 7,5 jam per hari. (Bandingkan dengan rata-rata $1 \mathrm{HOK}$ untuk laki-laki yaitu 7 jam kerja dan perempuan 0,7 HKP = hari kerja laki-laki).

Perempuan sebagai istri mempunyai peran yang berhubungan dengan kedudukkannya sebagai ibu rumahtangga. Aktivitas-aktivitas dalam rumahtangga merupakan realisasi peran di dalam rumahtangga yang dikenal pula sebagai produksi domestik. Secara perlahan-lahan perempuan tidak lagi terbelenggu dalam peran domestik saja. Hal ini disebabkan semakin beratnya tuntutan untuk memenuhi kebutuhan hidup rumahtangga.

Secara keseluruhan seluruh aktivitas perempuan baik dalam rumah maupun aktivitas di luar rumahtangga di dominasi oleh istri sebagai pedagang sayuran yakni sebesar 15 jam/hari dibandingkan dengan anggota rumahtangga lainnya dalam keluarga. Hal ini mengindikasikan bahwa rumahtangga pedagang sayuran lebih mengutamakan bekerja sebagai penjual sayuran dibandingkan dengan pekerjaan lain. Hal ini sesuai dengan hasil wawancara terhadap seluruh responden yang menyatakan bahwa usaha menjual sayuran ini merupakan mata pencaharian utama. Dengan demikian peranan istri dalam rumahtangga sangat penting, dimana istri berperan sebagai ibu rumahtangga dan sebagai pekerja dalam memenuhi kebutuhan hidup rumahtangga.

Berdasarkan Tabel 6, kebiasaan ibu rumah tangga untuk bangun pagi yakni sekitar jam 02.00 - 03.00 subuh, rata-rata sama dengan perempuan penjual sayuran yang lain namun berbeda dengan kebiasaan ibu-ibu kebanyakan yang lain yang bukan pedagang sayuran di pasar. Berdasarkan hasil wawancara ada yang melakukan doa pagi namun ada juga ibu-ibu yang tidak melakukan itu. Menyiapkan sarapan pagi sudah rutin dilakukan oleh ibu-ibu untuk suami yang juga akan bekerja. Jika mereka terlambat dari jam 3 subuh untuk ke pasar, mereka tidak mendapatkan sayuran sebagai bahan dagangan yang berasal dari supplier atau pedagang pengumpul. Konsekuensinya, bahan sayuran akan didapatkan dengan harga yang mahal. Untuk kegiatan arisan, kegiatan PKK atau ibadah kelompok tidak setiap hari dilakukan sehingga kalau tidak ada kegiatankegiatan tersebut di luar rumah pada jam-jam
16.00-19.00 aktivitas/kegiatan dilakukan di rumah sambil menonton televisi.

Dengan demikian penelitian ini memberikan suatu gambaran mengenai alokasi waktu yang dicurahkan pada kegiatan produksi dan reproduksi, baik oleh perempuan pedagang sayuran maupun anggota rumah tangga lain, dan kontribusi pendapatan yang berasal dari penjualan sayuran terhadap pendapatan rumah tangga. Umumnya, perempuan lebih banyak mencurahkan waktunya pada kegiatan rumah tangga dibandingkan dengan suami mereka. Suami, sebaliknya lebih banyak mencurahkan waktunya untuk kegiatan lain, yaitu aktivitas mencari nafkah di luar berjualan sayuran dan di luar kegiatan rumah tangga. Effendi (1990) dari penelitiannnya di Jatinom, Jawa Tengah membenarkan bahwa kegiatan di luar pertanian merupakan salah satu strategi kelangsungan hidup (survival strategy) rumah tangga.

Kegiatan tersebut memberikan peluang berusaha, merangsang pertumbuhan ekonomi dan mampu menekan migrasi tenaga kerja ke luar daerah. Bagi seorang perempuan, aktivitas berjualan sayuran memberikan keuntungan bekerja karena bidang pekerjaan ini cenderung merupakan perluasan kegiatan rumah tangga, baik dilihat dari jenis aktivitas maupun kemudahan usaha. Bentuk nyata dari keuntungan yang diperoleh perempuan adalah merealisasikan kemampuan mereka sebagai pencari nafkah utama atau pencari nafkah tambahan. Namun yang lebih penting adalah dalam aktivitas penjualan sayuran ini, perempuan dapat menemukan kebebasan finansial dari suami, bahkan beberapa perempuan sama sekali menggantikan fungsi suami sebagai pencari nafkah utama.

\section{Kontribusi Perempuan Pedagang Sayuran terhadap Pendapatan Rumah Tangga}

Perempuan pedagang sayuran dengan sendirinya memiliki kontribusi pendapatan terhadap pendapatan total rumahtangga. Dengan memaparkan kontribusi pendapatan dapat dilihat anggota keluarga mana yang memiliki peran yang besar terhadap pendapatan total rumahtangga. Disamping itu dapat diketahui usaha atau pekerjaan lain yang memberikan kontribusi paling besar. 
Berdasarkan Tabel 7 dapat dijelaskan bahwa pendapatan dari masing-masing anggota rumahtangga dihitung dalam $\mathrm{Rp} / \mathrm{bulan}$, tampak bahwa pendapatan tertinggi diperoleh istri dengan rata-rata pendapatan Rp 4.400 .050 per bulan dengan kontribusi sebesar 59,27 \%. Sumbangan atau kontribusi suami dalam pendapatan keluarga lebih rendah dari istri yakni sebesar 19,09\% terhadap pendapatan rumah tangga dengan rata-rata pendapatan suami sebesar Rp 1.417.000/bulan. Sumbangan anggota rumah tangga dari anak yang belum menikah dan tinggal serumah dengan responden sebesar Rp 1.607.000 per bulan $(21,64 \%)$. Jumlah kontribusi dari anak yang belum menikah ini masih lebih tinggi dibandingkan dengan kontribusi dari pendapatan suami.

Kontribusi pendapatan setiap anggota rumahtangga pada setiap aktivitas kerjanya yang lebih besar merupakan konsekuensi dari proporsi curahan kerja setiap anggota keluarga yang besar pada aktivitas tersebut. Dari total pendapatan rumahtangga dapat diungkapkan bahwa kontribusi istri sebagai ibu rumahtangga yang berdagang sayuran di pasar, lebih besar dari kontribusi suami dan anggota keluarga lainnya. Hal ini menunjukkan bahwa setiap anggota keluarga bersama-sama mencari nafkah untuk memenuhi kebutuhan hidup rumahtangganya. Ware (1981) mengemukakan bahwa ada dua alasan pokok yang melatarbelakangi keterlibatan perempuan dalam angkatan kerja. Pertama adalah "harus", yang mencerminkan kondisi ekonomi rumah tangga yang bersangkutan rendah sehingga bekerja untuk meringankan beban rumah tangga adalah penting. Perempuan pada golongan pertama ini pada umumnya berasal dari masyarakat yang status sosial ekonominya rendah. Kedua adalah "memilih untuk bekerja", yang mencerminkan kondisi sosial ekonomi pada tingkat menengah ke atas.

Pendapatan kepala rumah tangga sudah dirasa cukup memenuhi kebutuhan rumah tangga sehingga masuknya Perempuan pada angkatan kerja semata-mata bukan karena tekanan ekonomi. Keterlibatan mereka karena motivasi tertentu seperti, mencari kesibukan untuk mengisi waktu luang, mencari kepuasan diri, mencari afiliasi diri, atau mencari tambahan penghasilan.
Oleh karena itu, semakin rendah tingkat sosial ekonomi suatu masyarakat, maka tingkat partisipasi angkatan kerja perempuan cenderung semakin meningkat pula. Faktor hambatan ideologis yang berupa keterikatan perempuan pada kegiatan rumah tangga akan membatasi ruang gerak sehingga ia akan memilih pekerjaan yang paling mudah untuk digelutinya, karena faktor tersebut sangat berpengaruh terhadap kesempatan perempuan untuk memasuki lapangan kerja.

\section{KESIMPULAN DAN SARAN}

\section{Kesimpulan}

Berdasarkan hasil penelitian, maka dapat ditarik kesimpulan sebagai berikut:

1. Pola alokasi waktu oleh perempuan yang berdagang sayuran di Pasar Pinasungkulan Karombasan Manado lebih banyak mencurahkan waktunya $(59,40 \%)$ untuk berjualan sayuran (economic production) dibandingkan dengan mengurus rumahtangga (domestic production) $(17,30 \%)$, sehingga usaha ini merupakan aktivitas perempuan sebagai pencari nafkah utama dalam keluarga.

2. Kontribusi pendapatan perempuan sebagai ibu rumah tangga yang berusaha di bidang penjualan sayuran di pasar sekitar 59,27 persen terhadap pendapatan rumah tangga.

\section{Saran}

Berdasarkan kesimpulan yang telah dikemukakan, maka beberapa saran sebagai berikut:

1. Usaha ini memberikan potensi dan peluang yang sangat menjanjikan bagi perempuan dalam meningkatkan pendapatan dalam keluarga sehingga pendapatan yang diperoleh bisa disisihkan untuk tabungan dan modal usaha.

2. Karena perempuan sebagai pencari nafkah utama, maka diperlukan penelitian lanjutan tentang pola pengambilan keputusan dalam keluarga, khususnya bagi perempuan pedagang sayuran di pasar. 


\section{DAFTAR PUSTAKA}

Budiman, A. 2012. Pembagian kerja secara seksual sebuah pembahahasan sosiologis tentang peran wanita di dalam masyarakat. Jakarta: Gramedia.

Duwit, Beatrix S., Veronica, A. Kumurur., dan Ingerid, A. Moniaga. 2015. Persepsi Pedagang Kaki Lima Terhadap Area Berjualan Sepanjang Jalan Pasar Pinasungkulan Karombasan Manado. Jurnal Sabua Vol. 7, No. 2: hal 419-427 Oktober 2015. ISSN.

Hernanto, F. 1989. Ilmu Usahatani. Penebar Swadaya. Jakarta.

Husin, Laila dan Dwi Wulansari. 2011. Perilaku Ekonomi Rumahtangga Petani Karet di Prabumulih dalam Alokasi Tenaga Kerja Produksi dan Konsumsi. Laporan penelitian. Jurusan Sosial Ekonomi Pertanian Universitas Sriwijaya.

Mubyarto. 2004. Pengantar Ekonomi Pertanian. LP3ES. Jakarta.

Mulyadi, S. . 2000.Ekonomi Sumber Daya Manusia dalam Perspektif Pembangunan. PT. Raja Grafindo Persada. Jakarta.

Munandar, S. C. 2006. Emansipasi dan Peran Ganda Wanita Indonesia Suatu Tinjauan Psikologis. UI Press. Jakarta.

Oey, May Ling. 2005. "Perubahan pola kerja kaum wanita di Indonesia selama dasawarsa 1970 sebab dan akibatnya", Prisma 14(10).
Prayitno, W. 1991. Analisa Situasi Wanita Indonesia. Kantor Menteri Negara Urusan Peranan Wanita. Jakarta.

Rakomole, D. 2016. Peranan Wanita Pedagang Sayuran Terhadap Pendapatan Keluarga di Pasar Pinasungkulan Karombasan Manado. Skripsi. Fakultas Pertanian Universitas Sam Ratulangi. Manado.

Sayogyo, P. 2007. Peranan Wanita Dalam Perkembangan Masyarakat Desa. CV. Rajawali. Jakarta.

Sobari, M.P., Facrudin, A. dan Sujana. 1996. Pembagian Kerja dan Alokasi Waktu Pencarian Nafkah pada Rumah Tangga Pengambil Rumput Laut Alam di Kecamatan Cikelet, Kabupaten Garut. Buletin Ekonomi Perikanan No. 2 Tahun Ke 2. 1996.

Soekartawi. 2003. Agribisnis Teori dan Aplikasi. PT. Raja Grafindo Persada. Jakarta.

Sugiyono, 2003. Metode Penelitian Administrasi. Alfabeta. Bandung.

Soekanto Soerjono, 2012, “ Sosiologi Suatu Pengantar ", Rajawali Pers, Jakarta

Tambunan, K. 2009. Tenaga Kerja Wanita Indonesia. Pusat Dokumentasi dan Informasi Ilmiah. Jakarta

Widarti, S. 1984. Wanita Bakul di Pedesaan Jawa. Kanisius. Yogyakarta

Ware, K. 1981. Kemiskinan dan Kebutuhan Pokok. Rajawali Press. Jakarta.

Wolfman, B. R. 1986. Peranan Kaum Wanita. Kanisius. Yogyakarta 